\title{
Emerging pharmacological tools to control hydrogen sulfide signaling in critical illness
}

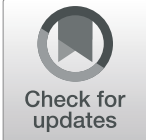

\author{
Eizo Marutani* ${ }^{*}$ and Fumito Ichinose
}

\author{
* Correspondence: emarutani@mgh. \\ harvard.edu \\ Department of Anesthesia, Critical \\ Care and Pain Medicine, \\ Massachusetts General Hospital and \\ Harvard Medical School, Boston, MA \\ 02114, USA
}

\begin{abstract}
Hydrogen sulfide $\left(\mathrm{H}_{2} \mathrm{~S}\right)$ has long been known as a toxic environmental hazard. Discovery of physiological roles of $\mathrm{H}_{2} \mathrm{~S}$ as a neurotransmitter by Kimura and colleagues triggered an intensive research in the biological roles of $\mathrm{H}_{2} \mathrm{~S}$ in the past decades. Manipulation of $\mathrm{H}_{2} \mathrm{~S}$ levels by inhibiting $\mathrm{H}_{2} \mathrm{~S}$ synthesis or administration of $\mathrm{H}_{2} \mathrm{~S}$-releasing molecules revealed beneficial as well as harmful effects of $\mathrm{H}_{2} \mathrm{~S}$. As a result, it is now established that $\mathrm{H}_{2} \mathrm{~S}$ levels are tightly controlled and too much or too little $\mathrm{H}_{2} \mathrm{~S}$ levels cause harm. Nonetheless, translation of sulfide-based therapy to clinical practice has been stymied due to the very low therapeutic index of sulfide and the incomplete understanding of endogenous sulfide metabolism. One potential strategy to circumvent this problem is to use a safe and stable sulfide metabolite that may mediate effects of $\mathrm{H}_{2} \mathrm{~S}$. Alternatively, endogenous sulfide levels may be controlled using specific sulfide scavengers. In this review article, the role of endogenous $\mathrm{H}_{2} \mathrm{~S}$ production and catabolism will be briefly reviewed followed by an introduction of thiosulfate and $\mathrm{H}_{2} \mathrm{~S}$ scavengers as novel pharmacological tools to control $\mathrm{H}_{2} \mathrm{~S}$-dependent signaling.

Keywords: Hydrogen sulfide, Sulfide synthesis, Sulfide catabolism, Sodium thiosulfate, Critical illness
\end{abstract}

\section{Background}

Hydrogen sulfide $\left(\mathrm{H}_{2} \mathrm{~S}\right)$ is a colorless gas with characteristic rotten egg odor, which has long been known as a toxic environmental pollutant [1]. Recently, $\mathrm{H}_{2} \mathrm{~S}$ has emerged as an important gaseous signaling molecule that is generated endogenously in tissues along with nitric oxide (NO) and carbon monoxide (CO) [2-4]. In 1996, Abe and Kimura reported a physiological role of $\mathrm{H}_{2} \mathrm{~S}$ as a neurotransmitter and identified cystathionine $\beta$ synthase (CBS) as an $\mathrm{H}_{2} \mathrm{~S}$-producing enzyme [5]. Intensive research thereafter revealed a number of physiological roles of $\mathrm{H}_{2} \mathrm{~S}$ including vasodilation, angiogenesis, anti/pro-inflammation, oxygen $\left(\mathrm{O}_{2}\right)$ sensing, and cytoprotection [6-8]. These studies showed that endogenous $\mathrm{H}_{2} \mathrm{~S}$ metabolisms (production and catabolism) play critical roles both in normal physiology and in some human disorders. Manipulation of $\mathrm{H}_{2} \mathrm{~S}$ levels by inhibiting $\mathrm{H}_{2} \mathrm{~S}$ synthesis or administration of $\mathrm{H}_{2} \mathrm{~S}$-releasing molecules revealed beneficial as well as harmful effects of $\mathrm{H}_{2} \mathrm{~S}$ [9-14]. Too much or too little $\mathrm{H}_{2} \mathrm{~S}$ levels appear to cause harm. For example, deficiency in CBS or another $\mathrm{H}_{2} \mathrm{~S}$-synthesis enzyme cystathionine $\gamma$-lyase (CSE or CTH) causes hypertension in mice $[15,16]$. While high-dose sodium sulfide $\left(\mathrm{Na}_{2} \mathrm{~S}\right)$, a $\mathrm{H}_{2} \mathrm{~S}$-donating compound, exaggerates ischemic brain injury, low-dose $\mathrm{Na}_{2} \mathrm{~S}$ or

(c) The Author(s). 2020 Open Access This article is distributed under the terms of the Creative Commons Attribution 4.0 International License (http://creativecommons.org/licenses/by/4.0/), which permits unrestricted use, distribution, and reproduction in any medium, provided you give appropriate credit to the original author(s) and the source, provide a link to the Creative Commons license, and indicate if changes were made. 
inhibitors of CSE or CBS decreases ischemic stroke size [17]. Deficiency in CSE promotes neurodegeneration in Huntington's disease [18], whereas deficiency in ethylmalonic encephalopathy 1 (ETHE1 or persulfide dioxygenase, $\mathrm{PDO}$ ), a $\mathrm{H}_{2} \mathrm{~S}$ catabolizing enzyme, is a cause of ethylmalonic encephalopathy, which is characterized by abnormally high $\mathrm{H}_{2} \mathrm{~S}$ levels in tissues and blood [19]. These observations indicate that dysregulated $\mathrm{H}_{2} \mathrm{~S}$ metabolism may be pathogenic. However, controlling sulfide levels has proven to be very difficult using chemical $\mathrm{H}_{2} \mathrm{~S}$ donors or inhibitors of $\mathrm{H}_{2} \mathrm{~S}$-producing enzymes. In recent studies, we revealed thiosulfate, an oxidative metabolite of $\mathrm{H}_{2} \mathrm{~S}$, may hold promise as a low toxicity sulfide donor. We also developed specific $\mathrm{H}_{2} \mathrm{~S}$ scavenger to control local concentration of $\mathrm{H}_{2} \mathrm{~S}$. We will review the role of endogenous $\mathrm{H}_{2} \mathrm{~S}$ production and catabolism followed by a focused discussion of thiosulfate and $\mathrm{H}_{2} \mathrm{~S}$ scavengers as emerging pharmacological strategies to control $\mathrm{H}_{2} \mathrm{~S}$-dependent signaling.

\section{Endogenous $\mathrm{H}_{2} \mathrm{~S}$ production}

Studies have revealed enzymatic and non-enzymatic $\mathrm{H}_{2} \mathrm{~S}$-producing pathways (Fig. 1). In enzymatic pathways, CBS, CSE, 3-mercaptopyruvate sulfurtransferase (3-MST), and cysteinyl-tRNA synthetase (CARS) contribute to endogenous production of $\mathrm{H}_{2} \mathrm{~S}$ directly or indirectly [20-23]. Approximately one fifth of sulfide exists as hydrosulfide ion (HS ${ }^{-}$) and the remaining four fifth consist mostly of $\mathrm{H}_{2} \mathrm{~S}$ with little amount of $\mathrm{S}^{2-}$ in physiological fluids $\left(37^{\circ} \mathrm{C}, \mathrm{pH}\right.$ 7.4) according to the Henderson-Hasselbalch equation [24].

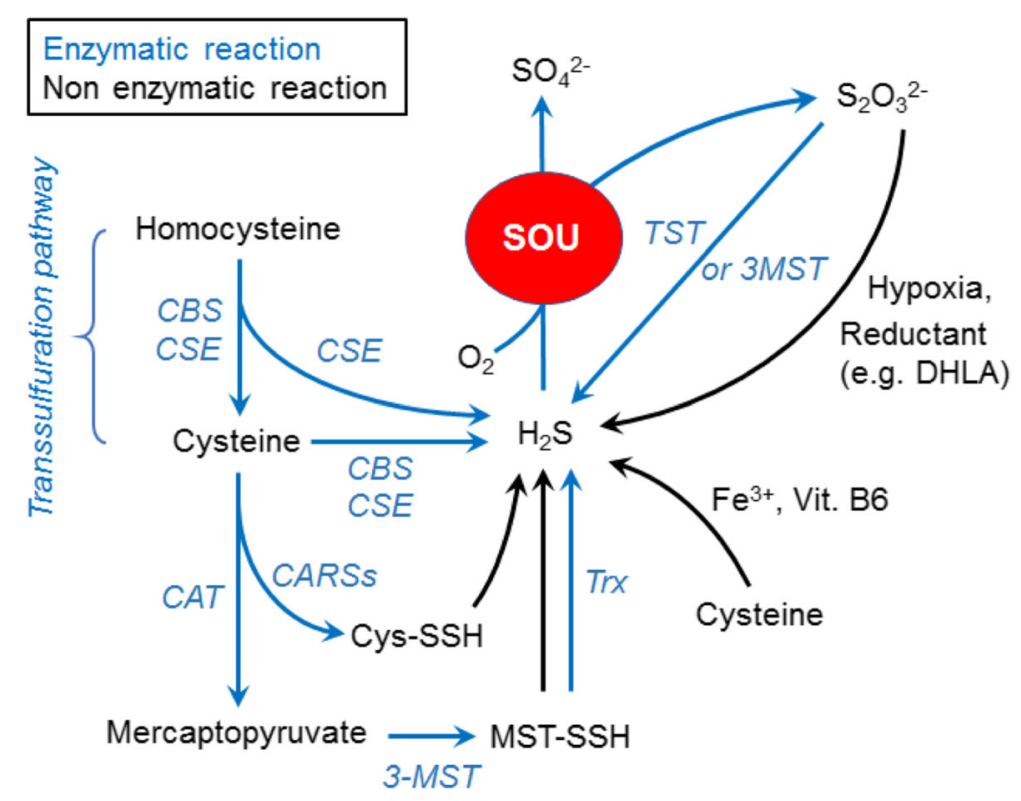

Fig. 1 Pathways of $\mathrm{H}_{2} \mathrm{~S}$ production. Cysteine is produced from homocysteine via transsulfuration pathway mediated by cystathionine $\beta$-synthase (CBS) and cystathionine gamma-lyase (CSE, CGL or CTH). $\mathrm{H}_{2} \mathrm{~S}$ is produced from homocysteine and cysteine by CBS and CSE. 3-Mercaptopyruvate sulfurtransferase (3-MST) generates 3-MST-cysteine persulfide (MST-SSH) utilizing mercaptopyruvate which is produced from cysteine by cysteine aminotransferase (CAT). $\mathrm{H}_{2} \mathrm{~S}$ is released from MST-SSH via non-enzymatic reaction or catalytic activity of thioredoxin ( $T r x)$. $\mathrm{H}_{2} \mathrm{~S}$ is oxidized by sulfide oxidation unit (SOU) to produce thiosulfate and sulfate utilizing $\mathrm{O}_{2}$ as described in the " $\mathrm{H}_{2} \mathrm{~S}$ catabolism" section. $\mathrm{H}_{2} \mathrm{~S}$ is generated from thiosulfate by nonenzymatic reaction using reductants in hypoxia or catalytic activity of thiosulfate sulfurtransferase (TST) or 3MST. $\mathrm{H}_{2} \mathrm{~S}$ is non-enzymatically produced from cysteine in an iron $\left(\mathrm{Fe}^{3+}\right)$ - and vitamin $\mathrm{B}_{6}$-dependent manner 
The transsulfuration pathway is a metabolic pathway where transfer of sulfur from homocysteine to cysteine occurs [25]. Products of this pathway include various sulfur metabolites such as cysteine, glutathione, and $\mathrm{H}_{2} \mathrm{~S}$. CBS and CSE produce $\mathrm{H}_{2} \mathrm{~S}$ from cysteine and homocysteine requiring a cofactor pyridoxal 5'-phosphate (PLP) via the transsulfuration pathway. CBS and CSE are mainly localized in cytosol while some reports suggest that CBS or CSE could translocate into mitochondria under hypoxic stress or conditions that increased intracellular free calcium, respectively [26, 27]. Driving catabolic $\mathrm{H}_{2} \mathrm{~S}$ oxidation is significant electron source for electron transport chain (ETC) as described below in this review [28-30]. Translocation of CSE from cytosol to mitochondria is important to maintain ATP level in hypoxia in vascular smooth muscle cells [27]. These observations indicate the important role of $\mathrm{H}_{2} \mathrm{~S}$ produced by $\mathrm{CBS}$ and CSE in maintenance of ATP production in hypoxia. Deficiency in CBS or CSE causes marked hyperhomocysteinemia and hypertension in mice $[15,16]$. Disruption of CBS in mice causes metabolic osteoporosis that is prevented by supplementation of $\mathrm{H}_{2} \mathrm{~S}$ [31]. Deficiency in CSE promotes neurodegeneration in Huntington's disease [18]. CSE deficiency ameliorates acute liver failure (ALF) in mice [32].

3-MST is a sulfurtransferase that produces sulfane sulfur, a sulfur atom with six valence electrons, rather than $\mathrm{H}_{2} \mathrm{~S}$. 3-Mercaptopyruvate, a substrate of 3-MST, is produced by cysteine aminotransferase (CAT). 3-MST produces sulfane sulfur transferring sulfur in sulfane group of 3-mercaptopyruvate to other sulfur acceptor using zinc as a cofactor. $\mathrm{H}_{2} \mathrm{~S}$ is subsequently released from sulfane sulfur [23]. 3-MST localizes both in cytosol and mitochondria. Thiosulfate sulfurtransferase (rhodanese or TST) is also known as a sulfurtransferase in mitochondria which produces sulfane sulfur although biological activity of this enzyme remains poorly understood [23]. Deficiency in 3-MST augments anxiety-like behavior in mice [33].

CARSs have been found initially as an enzyme that mediates translation of proteins in prokaryotes and eukaryotes including mammals [21]. CARS-1 and CARS-2 are localized in cytosol and mitochondria, respectively. Polysulfidation (or persulfidation) at the cysteine residue of proteins has been recognized as a "post"-translational protein modification which could modulate catalytic activity of the protein by altering protein conformations and/or directly changing the activity of catalytic centers [34-37]. Akaike et al. found that CARSs mediate polysulfidation of proteins "during," but not post-, protein translation in a PLP-dependent manner. Because sulfane sulfur in protein polysulfide can be a source of $\mathrm{H}_{2} \mathrm{~S}$, CARS increases $\mathrm{H}_{2} \mathrm{~S}$ levels indirectly. Homozygous disruption of CARS-2 is embryonic lethal [21]. Heterozygous disruption of CARS-2 decreases the tissue levels of persulfide, polysulfide, sulfide, and thiosulfate, while other phenotypes of CARS- $2^{+/}$mouse remain to be elucidated because CARS knockout mice have been generated very recently [21].

Studies using inhibitors of $\mathrm{H}_{2} \mathrm{~S}$ synthesizing enzymes have suggested the biological role of endogenous $\mathrm{H}_{2} \mathrm{~S}$ production. However, most of the currently available inhibitors are far from ideal [38]. For example, DL-propargyl glycine (PAG or PGG) or aminooxyacetic acid (AOAA) is the most frequently used compound as a CSE or CBS inhibitor, respectively. Despite only L-isomer of PAG, but not D-isomer, inhibits CSE and D-isomer may be a nephrotoxin, many studies have used the mixture of both isomers [39-41]. PAG has been typically used in the range of $1-10 \mathrm{mM}$ which is significantly higher than $\mathrm{IC}_{50}(40 \mu \mathrm{M})$ possibly because of the limited cell permeability [40]. At millimolar concentrations, PAG 
also inhibits other enzymes such as aspartate aminotransferase and alanine aminotransferase $[42,43]$. Because $\mathrm{IC}_{50}$ of AOAA for CSE and CBS are in the similar range (2-8.5 $\mu \mathrm{M}$ and $1.1 \mu \mathrm{M}$, respectively), AOAA is not a specific CBS inhibitor [38]. More specific and less toxic inhibitors are required to examine precise roles of $\mathrm{H}_{2} \mathrm{~S}$ synthesizing enzymes.

There have been a number of non-enzymatic $\mathrm{H}_{2} \mathrm{~S}$ productions reported. Iron $\left(\mathrm{Fe}^{3+}\right)$ generates $\mathrm{H}_{2} \mathrm{~S}$ from cysteine in a vitamin $\mathrm{B}_{6}$ - and pyridoxal (or PLP)-dependent manner [44]. Regulation of $\mathrm{H}_{2} \mathrm{~S}$ production via this pathway may contribute to pathophysiology of conditions with iron dysregulation such as hemolysis, iron overload, and hemorrhagic disorders. $\mathrm{H}_{2} \mathrm{~S}$ can also be generated from thiosulfate, one of $\mathrm{H}_{2} \mathrm{~S}$ oxidation products, in the presence of an endogenous reductant (e.g., dihydrolipoic acid) without enzymes [45]. Interestingly, $\mathrm{H}_{2} \mathrm{~S}$ production via thiosulfate is augmented in hypoxic conditions [45].

\section{$\mathrm{H}_{2} \mathrm{~S}$ catabolism}

$\mathrm{H}_{2} \mathrm{~S}$ is catabolized via both enzymatic and non-enzymatic pathways (Fig. 2). In enzymatic catabolism, $\mathrm{H}_{2} \mathrm{~S}$ is oxidized serially by sulfide oxidation unit (SOU), a cluster of mitochondrial enzymes. SOU consists of sulfide: quinone oxidoreductase (SQR or SQOR), ETHE1 or sulfide dioxygenase (SDO), TST, and sulfite oxidase (SO) [30, 46]. $\mathrm{H}_{2} \mathrm{~S}$ is oxidized by $\mathrm{SQR}$ to generate sulfane sulfur $\left(\mathrm{S}^{0}\right)$ which has six valence electrons and no charge forming persulfide (SQRS-S). SQR utilizes the oxidized form of coenzyme $\mathrm{Q}(\mathrm{CoQ})$ as an electron acceptor through the $\mathrm{H}_{2} \mathrm{~S}$ oxidation to produce the reduced form of CoQ which is consumed to drive ETC. As the next step, SQR transfers sulfane sulfur to sulfur acceptors such as glutathione (GSH), sulfite $\left(\mathrm{SO}_{3}{ }^{2-}\right)$, cysteine, and homocysteine while SQR utilizes GSH as a dominant sulfur acceptor in the physiological conditions to produce glutathione persulfide (GSSH) which is the main product of $\mathrm{H}_{2} \mathrm{~S}$ oxidation mediated by SQR. ETHE1 converts GSSH into sulfite and GSH consuming oxygen. Sulfite is further catabolized by TST or SO to produce thiosulfate $\left(\mathrm{S}_{2} \mathrm{O}_{3}{ }^{2-}\right)$ or sulfate $\left(\mathrm{SO}_{4}{ }^{2-}\right)$, respectively. Thiosulfate can be converted back to $\mathrm{H}_{2} \mathrm{~S}$ via catabolism by $3-\mathrm{MST}$ and TST [45].

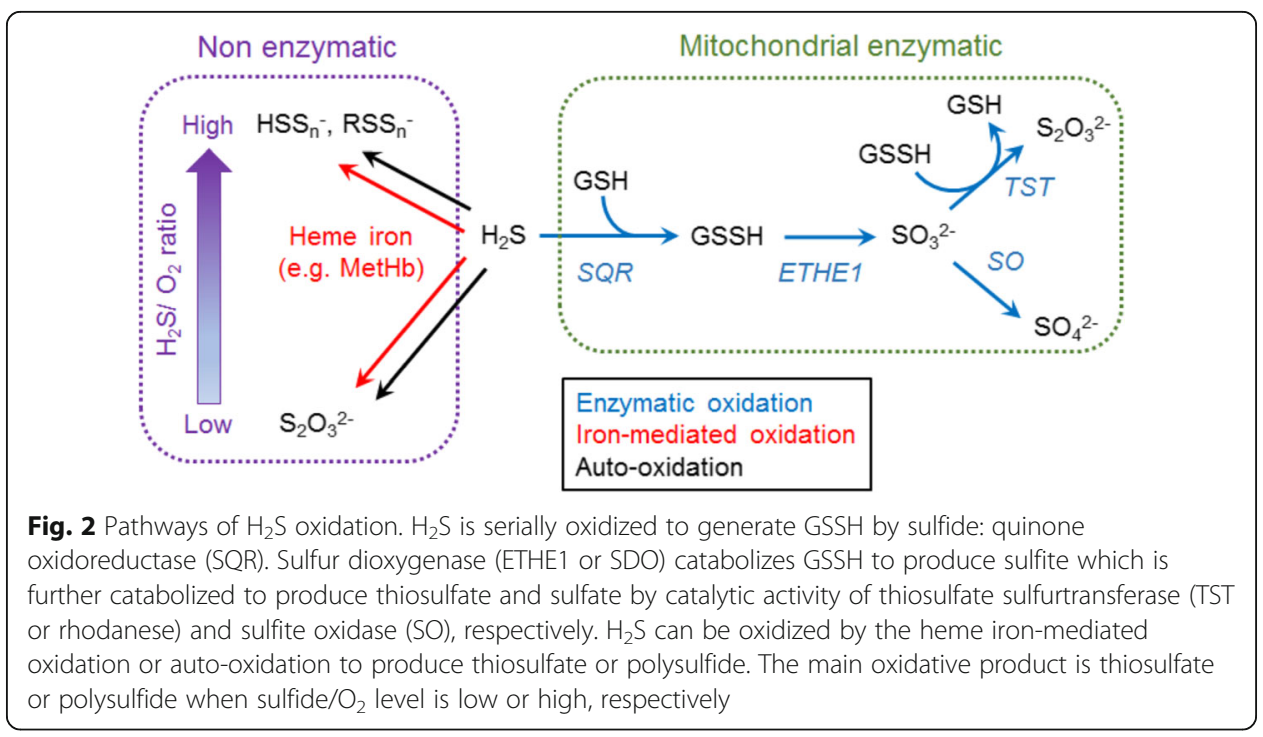


Non-enzymatic $\mathrm{H}_{2} \mathrm{~S}$ catabolic pathways play some roles. $\mathrm{H}_{2} \mathrm{~S}$ undergoes auto-oxidation both in aerobic and anaerobic conditions. High or low sulfide/oxygen ratio results in polysulfide or thiosulfate production in the buffer at physiological $\mathrm{pH}$, respectively [47]. $\mathrm{H}_{2} \mathrm{~S}$ also binds to heme iron of methemoglobin (MetHb) to be converted into thiosulfate and polysulfide [48]. MetHb is formed by auto-oxidation of ferrous $\mathrm{Hb}$ and represents $1-3 \%$ of total Hb. Therefore, MetHb concentration is $25-75 \mu \mathrm{M}$ in blood, which is significantly higher than circulating $\mathrm{H}_{2} \mathrm{~S}$ level $(\sim 0.2 \mu \mathrm{M})[48,49]$. This observation indicates that red blood cells play a critical role in maintaining circulating $\mathrm{H}_{2} \mathrm{~S}$ at physiologically low levels. Myoglobin can also exert similar capacity of $\mathrm{H}_{2} \mathrm{~S}$ oxidation as MetHb to generate thiosulfate and polysulfide [50]. $\mathrm{H}_{2} \mathrm{~S}$ can bind to other globin species (e.g., neuroglobin), which indicates the possible $\mathrm{H}_{2} \mathrm{~S}$ oxidation by these globin species [51-53].

Impairment of sulfide catabolism could be pathogenic. For example, mutation in ETHE1 is responsible for ethylmalonic encephalopathy [19, 54-56]. Ethylmalonic encephalopathy is an autosomal recessive disorder that affects several body systems, particularly the nervous system. Neurological signs and symptoms include delayed development and developmental regression, muscle weakness (hypotonia), seizures, and abnormal movements. ETHE1-deficient mice exhibit cardinal features of ethylmalonic encephalopathy and die between the fifth and sixth weeks after birth. ETHE1-deficient mice show sulfide accumulation and deterioration of complex IV activity in tissues including the brain.

Deficiency in TST markedly exacerbates, whereas TST activation by thiosulfate administration ameliorates, diabetes in mice [57]. TST expression level in human adipose tissue is correlated positively with adipose insulin sensitivity and negatively with fat mass, suggesting TST activation may be beneficial for type II diabetes.

\section{Administration of $\mathrm{H}_{2} \mathrm{~S}$ donor as therapeutic measure}

The effects of administration of exogenous $\mathrm{H}_{2} \mathrm{~S}$ were initially examined using simple sulfide salts (e.g., $\mathrm{Na}_{2} \mathrm{~S}, \mathrm{NaHS}$ ). For example, intra-left ventricular administration of $\mathrm{Na}_{2} \mathrm{~S}$ at $50 \mu \mathrm{g} / \mathrm{kg}$ attenuated myocardial ischemic injury by preserving mitochondrial function in mice [58]. Systemic administration of $\mathrm{Na}_{2} \mathrm{~S}$ at $7 \mu \mathrm{mol} / \mathrm{kg}$ IV improves survival rate and attenuates brain injury after cardiac arrest and cardiopulmonary resuscitation in mice via nitric oxide synthase 3-dependent manner [59]. Systemically administered sulfide salts increase circulating $\mathrm{H}_{2} \mathrm{~S}$ concentration instantly while $\mathrm{H}_{2} \mathrm{~S}$ levels return to the baseline quickly due to the short half-life of $\mathrm{H}_{2} \mathrm{~S}$ (shorter than 2 min in PBS and cell culture medium, around $4 \mathrm{~min}$ in the blood) [48, 60, 61]. Subsequently, a number of compounds that slowly release $\mathrm{H}_{2} \mathrm{~S}$ after administration were developed $[8,38,62]$. GYY4137, a water-soluble slowly $\mathrm{H}_{2} \mathrm{~S}$-releasing compound, exerts beneficial effects of $\mathrm{H}_{2} \mathrm{~S}$ even with wide therapeutic window (0.1-5 $\left.\mathrm{mM}\right)$ and has been used frequently in both in vitro and in vivo experiments [63]. Because $\mathrm{H}_{2} \mathrm{~S}$-induced neurotoxicity may be mediated via enhancement of $N$-methyl-D-aspartate receptor (NMDAR) activation [64-66], we developed a novel hybrid $\mathrm{H}_{2} \mathrm{~S}$-releasing molecule, Smemantine, which is a combination drug of slowly $\mathrm{H}_{2} \mathrm{~S}$-releasing molecule chemically conjugated with memantine which is a moderate NMDAR antagonist and approved for the treatment of Alzheimer's disease patients. S-memantine exerts lower toxicity and greater therapeutic effects against cerebral ischemic injury in vitro and in vivo than do $\mathrm{H}_{2} \mathrm{~S}$-releasing molecule alone or sulfide salt [60]. Some of $\mathrm{H}_{2} \mathrm{~S}$-releasing compounds 
have been tested in clinical trials [67-69]. Wallace and colleagues showed in a phase $2 \mathrm{~B}$ clinical trial that naproxen chemically conjugated with a $\mathrm{H}_{2} \mathrm{~S}$-releasing moiety, ATB-346, inhibits COX-2 as well as naproxen with less gastrointestinal damage than naproxen (ClinicalTrials.gov Identifier: NCT03978208, NCT03291418) [67]. Sodium polythionate (SG1002) is being assessed the ability to elevate plasma $\mathrm{H}_{2} \mathrm{~S}$ levels and to reduce markers of oxidative stress in heart failure patients in the phase II clinical trial (NCT01989208).

\section{Therapeutic effects of thiosulfate}

In a series of experimental studies, we unexpectedly uncovered therapeutic effects of thiosulfate in models of critical illnesses. Thiosulfate has traditionally been considered as an inert end product of $\mathrm{H}_{2} \mathrm{~S}$ oxidation. While sodium thiosulfate (STS) has been used as an antidote for cyanide poisoning, our discovery may expand its indication for other critical conditions.

We studied effects of inhaled $\mathrm{H}_{2} \mathrm{~S}$ in a murine model of endotoxin-induced systemic inflammation and shock. Before our study, some studies showed pro-inflammatory effects of $\mathrm{H}_{2} \mathrm{~S}$ whereas other studies reported anti-inflammatory effects of $\mathrm{H}_{2} \mathrm{~S}$. Our study revealed that endotoxin challenge decreased plasma sulfide concentration in mice. On the other hand, breathing $\mathrm{H}_{2} \mathrm{~S}$ after endotoxin challenge restored sulfide levels and increased thiosulfate concentrations in plasma (Fig. 3a, b) that lead to attenuated systemic inflammation and improved survival of mice. The increased thiosulfate levels in endotoxin-challenged mice that breathed $\mathrm{H}_{2} \mathrm{~S}$ appeared to be caused by endotoxininduced upregulation of TST. Based on these observations, we hypothesized that thiosulfate may contribute to the beneficial effects of $\mathrm{H}_{2} \mathrm{~S}$ inhalation. For the first time to our knowledge, we demonstrated that administration of STS dose-dependently improves survival rate of mice subjected to endotoxin challenge (Fig. 3c). These results put forth an innovative hypothesis that breathing $\mathrm{H}_{2} \mathrm{~S}$ exerts anti-inflammatory effects and improves survival during murine endotoxin shock, in part by remodeling sulfide metabolism and increasing thiosulfate levels [70].

To determine the role of endogenously produced $\mathrm{H}_{2} \mathrm{~S}$ on inflammatory organ injury, we examined the outcomes of D-galactosamine (GalN)/lipopolysaccharide (LPS)-induced ALF in CSE-deficient mice on the C57BL6 background. A combination of GalN/
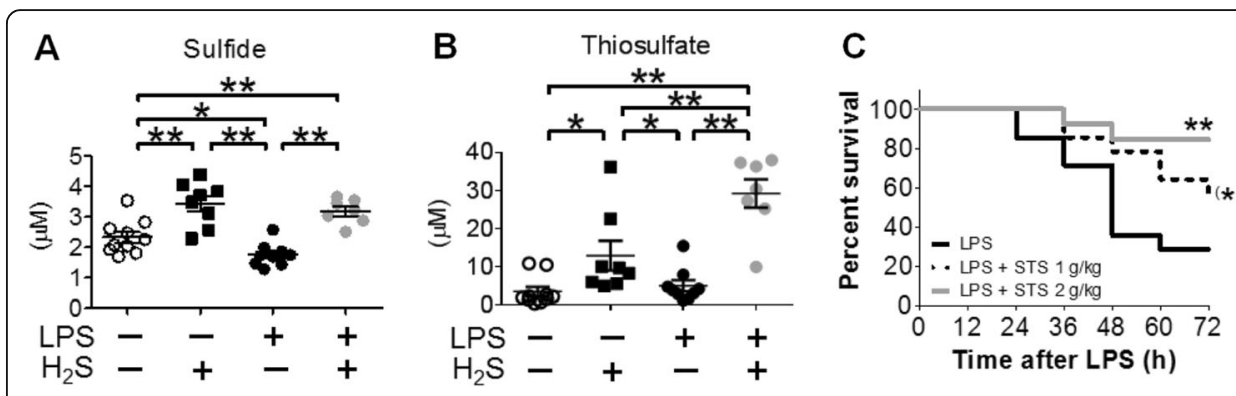

Fig. 3 Plasma a sulfide and $\mathbf{b}$ thiosulfate concentration of mice after lipopolysaccharide (LPS) challenge followed by $6 \mathrm{~h}$ inhalation of air with or without breathing $\mathrm{H}_{2} \mathrm{~S}(80 \mathrm{ppm}$ ) measured by monobromobimane-based high performance liquid chromatography (HPLC). ${ }^{*} P<0.05$ and ${ }^{* *} P=0.01$, respectively. c Survival curve in mice challenged with LPS (LPS, $N=14)$, mice challenged with LPS and received $1 \mathrm{~g} / \mathrm{kg}$ of STS (LPS + STS $1 \mathrm{~g} /$ $\mathrm{kg}, N=14)$, and mice challenged with LPS and received $2 \mathrm{~g} / \mathrm{kg}$ of STS (LPS + STS $2 \mathrm{~g} / \mathrm{kg}, N=13) .{ }^{*} P=$ 0.0047 vs. LPS; ${ }^{*} P=0.0781$ vs. LPS 
LPS has been widely used to induce ALF in animal models. GalN sensitizes the liver toward other stimuli in part reflecting the role of uridine-containing compounds in hepatic biotransformation. Coadministration of LPS and GalN potentiates hepatic damage, leading to hepatocyte apoptosis. Given the protective effects of physiological levels of $\mathrm{H}_{2} \mathrm{~S}$ against systemic inflammation, we hypothesized that CSE deficiency aggravates GalN/LPS-induced liver injury in mice. Unexpectedly, we observed that CSE deficiency attenuates liver injury and mortality in mice subjected to GalN/LPS-challenge, and prevents cell death in primary hepatocytes incubated with GalN/tumor necrosis factor (TNF)- $\alpha$. Beneficial effects of CSE deficiency were associated with markedly elevated homocysteine and thiosulfate levels, upregulation of NF-E2 p45-related factor 2 (Nrf2) and antioxidant proteins, and markedly increased 3-MST and SQR expression in the liver. Upregulation of 3-MST seemed to compensate the decrease in sulfide production by CSE deficiency. Because upregulated 3-MST and SQR in CSE-deficient mice may accelerate $\mathrm{H}_{2} \mathrm{~S}$ oxidation to thiosulfate, we again examined effects of STS in GalN/LPSinduced acute liver injury. We confirmed the robust cytoprotective effects of STS against acute liver failure (Fig. 4).

Another evidence that supports beneficial effects of thiosulfate came from our recent studies examining the mechanism of neuroprotective effects exerted by H2S donors. A number of studies suggest that $\mathrm{H}_{2} \mathrm{~S}$ attenuates ischemia/reperfusion (I/R) injury in a variety of organs including the brain, whether it is endogenously produced or exogenously administered as $\mathrm{H}_{2} \mathrm{~S}$ gas or donor compounds (typically $\mathrm{Na}_{2} \mathrm{~S}$ or $\mathrm{NaHS}$ ) [58-60, 71-73]. Nevertheless, mechanisms responsible for the cytoprotective effects of $\mathrm{H}_{2} \mathrm{~S}$ were incompletely defined. In particular, since $\mathrm{H}_{2} \mathrm{~S}$ has very short half-life in biological fluids including cell culture medium and blood, how $\mathrm{H}_{2} \mathrm{~S}$ reaches its presumed targets in the cells, and in the target tissues in the body when given in vivo, has been poorly understood. In this study, we showed that $\mathrm{H}_{2} \mathrm{~S}$ is mostly and quickly converted to thiosulfate in vitro and in vivo. While removal of thiosulfate from cell culture medium abolished the cytoprotective effects of $\mathrm{Na}_{2} \mathrm{~S}$ against oxygen glucose deprivation, replacement of thiosulfate restored

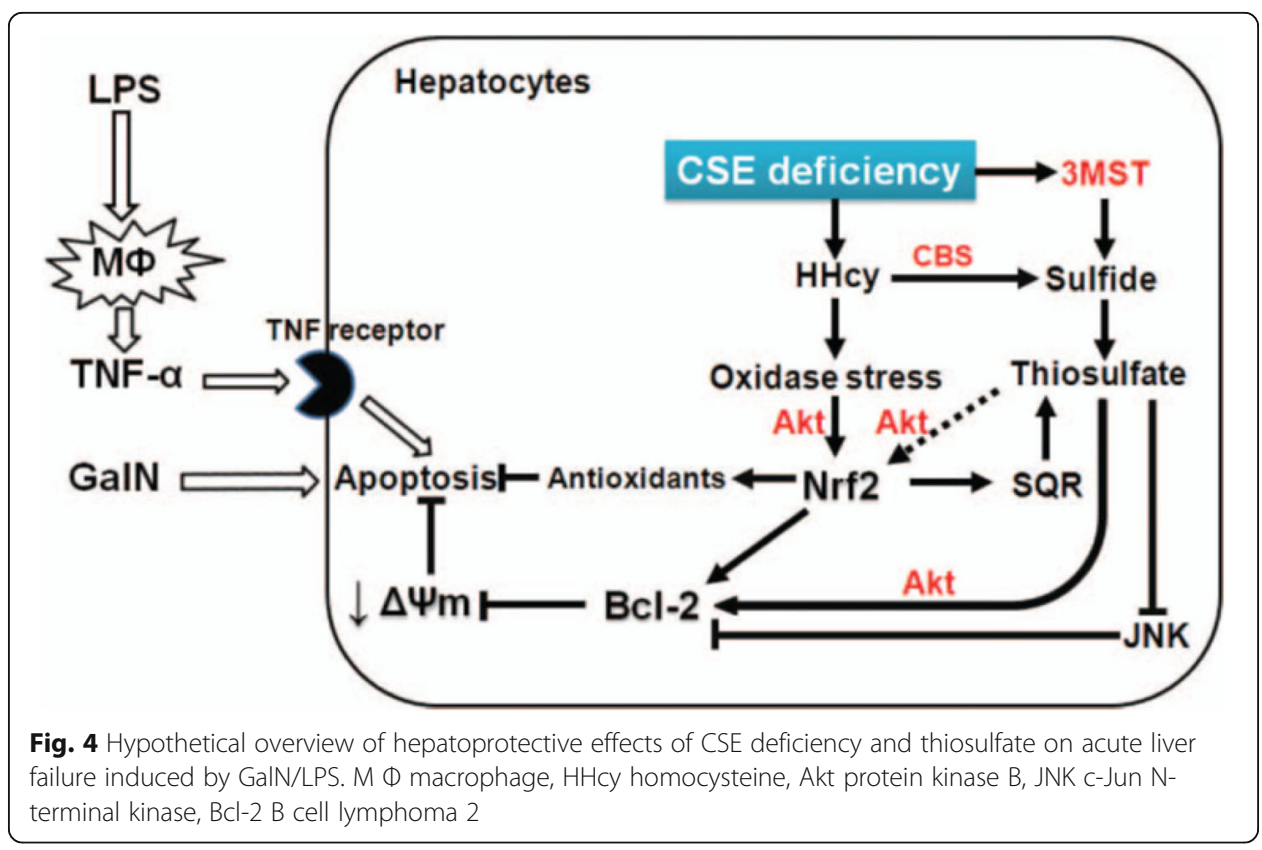


the protection. These results suggest that thiosulfate is not only required but sufficient for the cytoprotective effects of $\mathrm{H}_{2} \mathrm{~S}$. We observed that thiosulfate inhibits the mitochondrial apoptosis cascade and caspase- 3 activity. The cytoprotective effects of thiosulfate were associated with increased persulfidation of cleaved caspase-3 at Cys ${ }^{163}$. The protective effect of $\mathrm{Na}_{2} \mathrm{~S}$ or STS was facilitated by sodium sulfate cotransporter 2 (SLC13A4, NaS-2)-mediated transportation of thiosulfate across the cell membrane. Systemic administration of STS improved survival and neurological function of mice subjected to global cerebral I/R injury. Beneficial effects of STS, as well as $\mathrm{Na}_{2} \mathrm{~S}$, were associated with marked increase of thiosulfate, but not $\mathrm{H}_{2} \mathrm{~S}$, in plasma and brain tissues. These results suggest that thiosulfate is a circulating "carrier" molecule of cytoprotective effects of $\mathrm{H}_{2} \mathrm{~S}$.

Since STS is an inexpensive compound with low toxicity and proven safety track record of clinical use as an antidote for cyanide intoxication, STS is one of the most clinically relevant $\mathrm{H}_{2} \mathrm{~S}$ - or reactive sulfur species-related compounds. STS has also been used to treat calciphylaxis, a potentially lethal complication of hemodialysis [74]. Effects of STS against ischemic heart diseases are currently examined in a clinical trial (NCT02899364). However, precise mechanisms responsible for the beneficial effects of STS in inflammation, ischemia-reperfusion, and calciphylaxis remain incompletely understood. Although our studies showed the possibility that thiosulfate itself may exert protective effects, it is also known that thiosulfate can be converted back to $\mathrm{HS}^{-}$ and persulfide/polysulfide directly or indirectly [75-77]. It is possible that several related sulfur molecules exert different and/or shared effects.

\section{Novel hydrogen sulfide scavengers to counter toxic effects of $\mathrm{H}_{\mathbf{2}} \mathrm{S}$}

Hydrogen sulfide $\left(\mathrm{H}_{2} \mathrm{~S}\right)$ is a highly toxic chemical hazard. Workers in industries including agriculture, petroleum, and sewage processing have been exposed to high concentration of $\mathrm{H}_{2} \mathrm{~S}$ accidentally $[1,78]$. As $\mathrm{H}_{2} \mathrm{~S}$ can be easily and inexpensively made at home from materials found in local stores, it has been increasingly used for suicide [79, 80]. Among toxic gases, $\mathrm{H}_{2} \mathrm{~S}$ is the second most common cause of death after $\mathrm{CO}$ [81]. Symptom of $\mathrm{H}_{2} \mathrm{~S}$ poisoning varies depending on the gas concentration breathed. When $\mathrm{H}_{2} \mathrm{~S}$ gas at $1000 \mathrm{ppm}$ or higher concentration was inhaled, victims become unconscious and their respiratory center paralyzed instantly with only one or two breath. This is so-called knockdown and caused by instant paralysis of the central nervous system (CNS). One-time exposure to $\mathrm{H}_{2} \mathrm{~S}$ can lead to long-term neurological deficits [82]. The US government considers $\mathrm{H}_{2} \mathrm{~S}$ a high priority chemical threat, both industrially and as a potential weapon of mass destruction by terrorists. Mechanism of $\mathrm{H}_{2} \mathrm{~S}$ poisoning is incompletely understood, and there is no antidote for $\mathrm{H}_{2} \mathrm{~S}$ intoxication. Sodium nitrite, hydroxocobalamin, thiosulfate, hyperbaric oxygen, and hypothermia have been used after acute $\mathrm{H}_{2} \mathrm{~S}$ poisoning with limited efficacy [81].

Toxic effects of $\mathrm{H}_{2} \mathrm{~S}$ are caused not only by exogenous $\mathrm{H}_{2} \mathrm{~S}$ but also by accumulation of endogenous $\mathrm{H}_{2} \mathrm{~S}$. Several observations indicate that $\mathrm{H}_{2} \mathrm{~S}$ toxicity could be induced by disruption of endogenous $\mathrm{H}_{2} \mathrm{~S}$-production/catabolism balance. For example, ETHE1 deficiency is a cause of ethylmalonic encephalopathy. Cardinal features of ethylmalonic encephalopathy are associated with extreme elevation of circulating and tissue $\mathrm{H}_{2} \mathrm{~S}$ levels [19]. $\mathrm{H}_{2} \mathrm{~S}$ accumulates in hypoxic conditions due to the inhibition of SOU activity and decreased spontaneous oxidation [49, 83, 84]. CBS and CSE could translocate into mitochondria in hypoxic condition as described above. Therefore, hypoxia possibly 
causes $\mathrm{H}_{2} \mathrm{~S}$ to accumulate to the toxic level in mitochondria. Qu et al. reported that accumulation of brain $\mathrm{H}_{2} \mathrm{~S}$ during ischemia is a possible mediator of the brain damage after permanent focal cerebral ischemia in mice [65]. They demonstrated that the increase in brain $\mathrm{H}_{2} \mathrm{~S}$ level is associated with cerebral ischemic injury and pre-ischemic inhibition of $\mathrm{H}_{2} \mathrm{~S}$-synthesis enzymes reduces cerebral infarct size. On the other hand, some reports have suggested the therapeutic effect of $\mathrm{H}_{2} \mathrm{~S}$-releasing compounds that are systemically administered early after reperfusion against cerebral ischemia/reperfusion [59, 60, 85, 86]. This apparent conflict about the role of $\mathrm{H}_{2} \mathrm{~S}$ in ischemia/reperfusion might be explained by the dynamics of tissue $\mathrm{H}_{2} \mathrm{~S}$ concentration during ischemia and after reperfusion as well as the narrow therapeutic window of $\mathrm{H}_{2} \mathrm{~S}$. Sulfide levels increase during ischemia and decrease after reperfusion in tissues, including brains [17, 65, 85, 87]. We and others reported that restoration of physiological sulfide levels mitigates I/R injury [58, 59, 85]. Although administration of low doses of sulfide donors at the time of or after reperfusion can activate several cytoprotective signaling cascades and attenuate reperfusion injury, slight overdose or delayed administration is often ineffective or harmful [58, 59, 85, 88]. Translation of sulfide-based therapy to clinical practice has been stymied due to the very low therapeutic index of sulfide $[58,60,89]$ and the incomplete understanding of endogenous sulfide metabolism during ischemia and after reperfusion. Although keeping sulfide concentrations in the narrow therapeutic range appears to be critical, currently available pharmacological tools (e.g., inhibitors of $\mathrm{H}_{2} \mathrm{~S}$-producing enzymes) fail to achieve this goal. These observations prompted us to explore the role of sulfide catabolism in cellular respiration and survival.

To better understand the role of sulfide catabolism and potentially develop countermeasures against $\mathrm{H}_{2} \mathrm{~S}$ poisoning, we recently launched a project to develop novel $\mathrm{H}_{2} \mathrm{~S}$-specific scavengers in collaboration with Xian laboratory [90]. To the best of our knowledge, specific $\mathrm{H}_{2} \mathrm{~S}$ scavengers to control endogenous $\mathrm{H}_{2} \mathrm{~S}$ levels have not been explored or reported. It should be noted that $\mathrm{H}_{2} \mathrm{~S}$ scavengers are well-known in industrial settings as the removal of $\mathrm{H}_{2} \mathrm{~S}$ or related sulfur-containing compounds in industrial processes has been extensively studied [91]. Materials like metallic oxide, alkanolamines, oxidizing chemicals, metal carboxylates/chelates, aldehydes, and triazines have been used as $\mathrm{H}_{2} \mathrm{~S}$ scavengers. Unfortunately, these industrial sulfide scavengers cannot be applied into biological systems because of toxicity. Several compounds are known and used clinically as antidotes for $\mathrm{H}_{2} \mathrm{~S}$ poisoning, but their specificity for $\mathrm{H}_{2} \mathrm{~S}$ and applications for $\mathrm{H}_{2} \mathrm{~S}$-related pathologies have not been studied. For example, hydroxocobalamin $(\mathrm{HC})$ has been investigated as an antidote for $\mathrm{H}_{2} \mathrm{~S}$ poisoning, but it also scavenges cyanide, NO, CO, and ROS [92-94]. In our recently published study, we identified a series of sulfonyl azide compounds as promising $\mathrm{H}_{2} \mathrm{~S}$ scavengers by exploiting the library of existing specific chemical $\mathrm{H}_{2} \mathrm{~S}$ sensors and conducting extensive in vitro and in vivo screening. Sulfonyl azide compounds exhibit fast reaction time with $\mathrm{H}_{2} \mathrm{~S}$, high specificity against sulfide, low cellular toxicity, and capability to remove $\mathrm{H}_{2} \mathrm{~S}$ in cellular systems. Systemic administration of SS20, one of these sulfonyl azide-based $\mathrm{H}_{2} \mathrm{~S}$ scavengers, prevented death in mice subjected to acute $\mathrm{H}_{2} \mathrm{~S}$ poisoning (Fig. 5) [90]. These results suggest that $\mathrm{H}_{2} \mathrm{~S}$ scavengers may function as effective antidotes for $\mathrm{H}_{2} \mathrm{~S}$ poisoning. Further studies are warranted to determine the effects of $\mathrm{H}_{2} \mathrm{~S}$ scavengers in situations where endogenous $\mathrm{H}_{2} \mathrm{~S}$ accumulation may be pathogenic. 


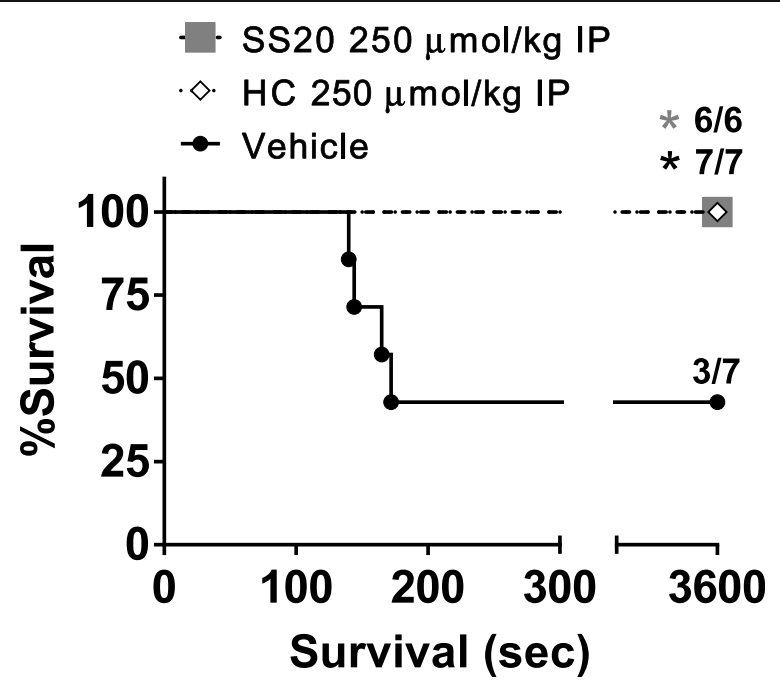

Fig. 5 Survival rate curve of mice intoxicated with $\mathrm{Na}_{2} \mathrm{~S}$ at $125 \mathrm{mg} / \mathrm{kg} \mathrm{IP}$. Vehicle (saline) or a $\mathrm{H}_{2} \mathrm{~S}$ scavenger (SS20 or hydroxocobalamin, $\mathrm{HC}$ ) was administered at 1 min after $\mathrm{Na}_{2} \mathrm{~S}$ challenge. $P<0.05$ vs. vehicle (saline)

\section{Conclusions}

Intensive research in the last decade established that $\mathrm{H}_{2} \mathrm{~S}$ is an important signaling molecule. Current knowledge indicates that dysregulated $\mathrm{H}_{2} \mathrm{~S}$ levels are linked to a number of pathological processes including cancer, inflammation, diabetes, hypertension, and neurodegenerative diseases [95-98]. Consequently, chemical compounds that can be used to precisely regulate local $\mathrm{H}_{2} \mathrm{~S}$ concentrations (both up and down) are important research tools as well as potential therapeutic agents. At the same time, it has become evident that currently available pharmacological tools are not sufficiently specific or versatile to elucidate the precise role of $\mathrm{H}_{2} \mathrm{~S}$ in biology. Our discovery that thiosulfate may be an important carrier molecule of the biological effects of $\mathrm{H}_{2} \mathrm{~S}$ may aid future research on the systemic effects of $\mathrm{H}_{2} \mathrm{~S}$. Recent development of specific $\mathrm{H}_{2} \mathrm{~S}$ scavengers will enable more mechanistic studies by removing $\mathrm{H}_{2} \mathrm{~S}$ from cellular milieu as well as propose a novel countermeasures against $\mathrm{H}_{2} \mathrm{~S}$ poisoning. Because therapeutic window of $\mathrm{H}_{2} \mathrm{~S}$ is narrow, to clarify how changes in balance of $\mathrm{H}_{2} \mathrm{~S}$ production and catabolism play in illness must lead to further strategy of $\mathrm{H}_{2} \mathrm{~S}$-based therapies. This balance alteration seems to depend on the type of tissues and illness due to the diversity of expression levels related to $\mathrm{H}_{2} \mathrm{~S}$ metabolism in tissues. For example, CNS is very sensitive to $\mathrm{H}_{2} \mathrm{~S}$ poisoning due to the minimal level of $\mathrm{H}_{2} \mathrm{~S}$ catabolizing capacity. Therefore, CNS seems to readily be affected by $\mathrm{H}_{2} \mathrm{~S}$ toxicity in illness that increases $\mathrm{H}_{2} \mathrm{~S}$ production $[65,99]$. Further researches for $\mathrm{H}_{2} \mathrm{~S}$-production/catabolism balance in illness as well as development of novel pharmacological tools will undoubtedly advance our understanding of this fascinating gaseous molecule.

\footnotetext{
Abbreviations

3-MST: 3-Mercaptopyruvate sulfurtransferase; ALF: Acute liver failure; AOAA: Aminooxyacetic acid; CARS: Cysteinyl-tRNA synthetase; CAT: Cysteine aminotransferase; CBS: Cystathionine $\beta$-synthase; CNS: Central nervous system; CO: Carbon monoxide; CoQ: Coenzyme Q; CSE: Cystathionine y-lyase; ETC: Electron transport chain; ETHE1: Ethylmalonic encephalopathy 1; GalN: D-Galactosamine; GSH: Glutathione; GSSH: Glutathione persulfide; $\mathrm{H}_{2} \mathrm{~S}$ : Hydrogen sulfide; HC: Hydroxocobalamin; I/R: Ischemia/reperfusion; LPS: Lipopolysaccharide; MetHb: Methemoglobin; NO: Nitric oxide; $\mathrm{O}_{2}$ : Oxygen; PAG: DL-Propargyl glycine; PLP: Pyridoxal 5'-phosphate; SDO: Sulfide dioxygenase; SO: Sulfite oxidase; SOU: Sulfide oxidation unit; SQR: Sulfide quinone oxidoreductase; STS: Sodium thiosulfate; TNF-a: Tumor necrosis factor; TST: Rhodanese or thiosulfate sulfurtransferase
} 
Acknowledgements

Not applicable.

About this supplement

Not applicable.

\section{Authors' contributions}

EM and FI conceived the review, performed the literature review, and drafted the first draft of the manuscript. Both authors read and approved the final manuscript.

\section{Funding}

This work has been supported by R01NS112373 to Dr. Ichinose.

Availability of data and materials

Not applicable.

Ethics approval and consent to participate

Not applicable.

\section{Consent for publication}

Not applicable.

\section{Competing interests}

The authors declare that they have no competing interests.

Received: 8 November 2019 Accepted: 20 January 2020

Published online: 31 January 2020

\section{References}

1. Reiffenstein RJ, Hulbert WC, Roth SH (1992) Toxicology of hydrogen sulfide. Annu Rev Pharmacol Toxicol 32:109-134

2. Lundberg JO, Gladwin MT, Weitzberg E (2015) Strategies to increase nitric oxide signalling in cardiovascular disease. Nat Rev Drug Discov 14:623

3. Calabrese V, Mancuso C, Calvani M, Rizzarelli E, Butterfield DA, Giuffrida Stella AM (2007) Nitric oxide in the central nervous system: neuroprotection versus neurotoxicity. Nat Rev Neurosci 8:766-775

4. Motterlini R, Otterbein LE (2010) The therapeutic potential of carbon monoxide. Nat Rev Drug Dis 9:728-743

5. Abe K, Kimura H (1996) The possible role of hydrogen sulfide as an endogenous neuromodulator. J Neurosci 16:10661071

6. Lefer D (2019) Redox pioneer: Professor hideo kimura. Antioxid Redox Signal 30:1699-1708

7. Das A, Huang GX, Bonkowski MS, Longchamp A, Li C, Schultz MB, Kim L-J, Osborne B, Joshi S, Lu Y, Treviño-Villarreal JH, Kang M-J, Hung T-T, Lee B, Williams EO, Igarashi M, Mitchell JR, Wu LE, Turner N, Arany Z, Guarente L, Sinclair DA (2018) Impairment of an endothelial $\mathrm{NAD}(+)-\mathrm{H}(2) \mathrm{S}$ signaling network is a reversible cause of vascular aging. Cell 173:74-89.e20

8. Wallace JL, Wang R (2015) Hydrogen sulfide-based therapeutics: exploiting a unique but ubiquitous gasotransmitter. Nat Rev Drug Dis 14:329

9. Blachier F, Davila A-M, Mimoun S, Benetti P-H, Atanasiu C, Andriamihaja M, Benamouzig R, Bouillaud F, Tomé D (2010) Luminal sulfide and large intestine mucosa: friend or foe? Amino Acids. 39:335-347

10. Akhil H, Madhav B (2011) Hydrogen sulfide in inflammation: friend or foe? Inflamm Allergy Drug Targets 10:118-122

11. Olas B (2014) Hydrogen sulfide in hemostasis: friend or foe? Chem Biol Interact 217:49-56

12. Kolluru GK, Shen X, Kevil CG (2013) A tale of two gases: $N O$ and $\mathrm{H}_{2} \mathrm{~S}$, foes or friends for life? Redox Biology. 1:313-318

13. Whiteman M, Winyard PG (2011) Hydrogen sulfide and inflammation: the good, the bad, the ugly and the promising. Expert Rev Clin Pharmacol 4:13-32

14. Dou Y, Wang Z, Chen G (2016) The role of hydrogen sulfide in stroke. Med Gas Res 6:79-84

15. Huang P, Chen S, Wang Y, Liu J, Yao Q, Huang Y, Li H, Zhu M, Wang S, Li L, Tang C, Tao Y, Yang G, Du J, Jin H (2015) Down-regulated $\mathrm{CBS} / \mathrm{H}_{2} \mathrm{~S}$ pathway is involved in high-salt-induced hypertension in Dahl rats. Nitric Oxide. 46:192-203

16. Yang G, Wu L, Jiang B, Yang W, Qi J, Cao K, Meng Q, Mustafa AK, Mu W, Zhang S, Snyder SH, Wang R (2008) $\mathrm{H}_{2} \mathrm{~S}$ as a physiologic vasorelaxant: hypertension in mice with deletion of cystathionine gamma-lyase. Science 322:587-590

17. Ren C, Du A, Li D, Sui J, Mayhan WG, Zhao H (2010) Dynamic change of hydrogen sulfide during global cerebral ischemia-reperfusion and its effect in rats. Brain Res 1345:197-205

18. Paul BD, Sbodio JI, Xu R, Vandiver MS, Cha JY, Snowman AM, Snyder SH (2014) Cystathionine Y-lyase deficiency mediates neurodegeneration in Huntington's disease. Nature. 509:96-100

19. Tiranti V, Viscomi C, Hildebrandt T, Di Meo I, Mineri R, Tiveron C, Levitt MD, Prelle A, Fagiolari G, Rimoldi M, Zeviani M (2009) Loss of ETHE1, a mitochondrial dioxygenase, causes fatal sulfide toxicity in ethylmalonic encephalopathy. Nat Med. 15:200-205

20. Shibuya N, Tanaka M, Yoshida M, Ogasawara Y, Togawa T, Ishii K, Kimura H (2008) 3-Mercaptopyruvate sulfurtransferase produces hydrogen sulfide and bound sulfane sulfur in the brain. Antioxid Redox Signal 11:703-714

21. Akaike T, Ida T, Wei F-Y, Nishida M, Kumagai Y, Alam MM, Ihara H, Sawa T, Matsunaga T, Kasamatsu S, Nishimura A, Morita M, Tomizawa K, Nishimura A, Watanabe S, Inaba K, Shima H, Tanuma N, Jung M, Fujii S, Watanabe Y, Ohmuraya M, Nagy P, Feelisch M, Fukuto JM, Motohashi H (2017) Cysteinyl-tRNA synthetase governs cysteine polysulfidation and mitochondrial bioenergetics. Nat Commun 8:1177-1177

22. Kimura H (2002) Hydrogen sulfide as a neuromodulator. Mol Neurobiol 26:13-19

23. Toohey II (2011) Sulfur signaling: is the agent sulfide or sulfane? Anal Biochem 413:1-7 
24. Dombkowski RA, Russell MJ, Olson KR (2004) Hydrogen sulfide as an endogenous regulator of vascular smooth muscle tone in trout. Am J Physiol Regul Integr Comp Physiol 286:R678-R685

25. Sbodio Jl, Snyder SH, Paul BD (2019) Regulators of the transsulfuration pathway. Br J Pharmacol 176:583-593

26. Teng H, Wu B, Zhao K, Yang G, Wu L, Wang R (2013) Oxygen-sensitive mitochondrial accumulation of cystathionine $\beta$ synthase mediated by Lon protease. Proc Natl Acad Sci 110:12679-12684

27. Fu M, Zhang W, Wu L, Yang G, Li H, Wang R (2012) Hydrogen sulfide $\left(\mathrm{H}_{2} \mathrm{~S}\right)$ metabolism in mitochondria and its regulatory role in energy production. Proc Natl Acad Sci U S A 109:2943-2948

28. Szabo C, Ransy C, Módis K, Andriamihaja M, Murghes B, Coletta C, Olah G, Yanagi K, Bouillaud F (2014) Regulation of mitochondrial bioenergetic function by hydrogen sulfide. Part I. Biochemical and physiological mechanisms. Br J Pharmacol 171:2099-2122

29. Módis K, Bos EM, Calzia E, van Goor H, Coletta C, Papapetropoulos A, Hellmich MR, Radermacher P, Bouillaud F, Szabo C (2014) Regulation of mitochondrial bioenergetic function by hydrogen sulfide. Part II. Pathophysiological and therapeutic aspects. Br J Pharmacol 171:2123-2146

30. Olson KR, Straub KD (2016) The role of hydrogen sulfide in evolution and the evolution of hydrogen sulfide in metabolism and signaling. Physiology. 31:60-72

31. Behera J, Kelly KE, Voor MJ, Metreveli N, Tyagi SC, Tyagi N (2018) Hydrogen sulfide promotes bone homeostasis by balancing inflammatory cytokine signaling in CBS-deficient mice through an epigenetic mechanism. Sci Rep 8:15226-15226

32. Shirozu K, Tokuda K, Marutani E, Lefer D, Wang R, Ichinose F (2013) Cystathionine $\gamma$-lyase deficiency protects mice from galactosamine/lipopolysaccharide-induced acute liver failure. Antioxid Redox Signal 20:204-216

33. Nagahara N, Nagano M, Ito T, Shimamura K, Akimoto T, Suzuki H (2013) Antioxidant enzyme, 3-mercaptopyruvate sulfurtransferase-knockout mice exhibit increased anxiety-like behaviors: a model for human mercaptolactate-cysteine disulfiduria. Sci Rep 3:1986-1986

34. Mustafa AK, Gadalla MM, Sen N, Kim S, Mu W, Gazi SK, Barrow RK, Yang G, Wang R, Snyder SH (2009) $\mathrm{H}_{2} \mathrm{~S}$ signals through protein s-sulfhydration. Sci Signal 2:ra72

35. Sen N, Paul Bindu D, Gadalla Moataz M, Mustafa Asif K, Sen T, Xu R, Kim S, Snyder SH (2012) Hydrogen sulfide-linked sulfhydration of NF-KB mediates its antiapoptotic actions. Mol Cell. 45:13-24

36. Kakinohana M, Marutani E, Tokuda K, Kida K, Kosugi S, Kasamatsu S, Magliocca A, Ikeda K, Kai S, Sakaguchi M, Hirai S, Xian M, Kaneki M, Ichinose F (2019) Breathing hydrogen sulfide prevents delayed paraplegia in mice. Free Radic Biol Med 131:243-250

37. Marutani E, Yamada M, Ida T, Tokuda K, Ikeda K, Kai S, Shirozu K, Hayashida K, Kosugi S, Hanaoka K, Kaneki M, Akaike T, Ichinose F (2015) Thiosulfate mediates cytoprotective effects of hydrogen sulfide against neuronal ischemia. J Am Heart Assoc 4

38. Szabo C, Papapetropoulos A (2017) International union of basic and clinical pharmacology. Cll: Pharmacological modulation of H(2)S levels: $\mathrm{H}(2) \mathrm{S}$ donors and H(2)S biosynthesis inhibitors. Pharmacol Rev. 69:497-564

39. Konno R, lkeda M, Yamaguchi K, Ueda Y, Niwa A (2000) Nephrotoxicity of D-propargylglycine in mice. Arch Toxicol 74:473-479

40. Asimakopoulou A, Panopoulos P, Chasapis CT, Coletta C, Zhou Z, Cirino G, Giannis A, Szabo C, Spyroulias GA, Papapetropoulos A (2013) Selectivity of commonly used pharmacological inhibitors for cystathionine $\beta$ synthase (CBS) and cystathionine $\gamma$ lyase (CSE). Br J Pharmacol 169:922-932

41. Maekawa M, Okamura T, Kasai N, Hori Y, Summer KH, Konno R (2005) D-amino-acid oxidase is involved in D-serineinduced nephrotoxicity. Chem Res Toxicol 18:1678-1682

42. Tanase S, Morino Y (1976) Irreversible inactivation of aspartate aminotransferases during transamination with Lpropargylglycine. Biochem Biophys Res Commun 68:1301-1308

43. Burnett G, Marcotte P, Walsh C (1980) Mechanism-based inactivation of pig heart L-alanine transaminase by Lpropargylglycine. Half-site reactivity. J Biol Chem 255:3487-3491

44. Yang J, Minkler P, Grove D, Wang R, Willard B, Dweik R, Hine C (2019) Non-enzymatic hydrogen sulfide production from cysteine in blood is catalyzed by iron and vitamin $B_{6}$. Commun Biol. 2:194-194

45. Olson KR, Deleon ER, Gao Y, Hurley K, Sadauskas V, Batz C, Stoy GF (2013) Thiosulfate: a readily accessible source of hydrogen sulfide in oxygen sensing. Am J Physiol Regul Integr Comp Physiol 305:R592-R603

46. Libiad M, Yadav PK, Vitvitsky V, Martinov M, Banerjee R (2014) Organization of the human mitochondrial hydrogen sulfide oxidation pathway. J Biol Chem 289:30901-30910

47. Chen KY, Morris JC (1972) Kinetics of oxidation of aqueous sulfide by oxygen. Environ Sci Technol 6:529-537

48. Vitvitsky V, Yadav PK, Kurthen A, Banerjee R (2015) Sulfide oxidation by a noncanonical pathway in red blood cells generates thiosulfate and polysulfides. J Biol Chem 290:8310-8320

49. Shen X, Peter EA, Bir S, Wang R, Kevil CG (2012) Analytical measurement of discrete hydrogen sulfide pools in biological specimens. Free Radic Biol Med 52:2276-2283

50. Bostelaar T, Vitvitsky V, Kumutima J, Lewis BE, Yadav PK, Brunold TC, Filipovic M, Lehnert N, Stemmler TL, Banerjee R (2016) Hydrogen sulfide oxidation by myoglobin. J Am Chem Soc 138:8476-8488

51. Brittain T, Yosaatmadja Y, Henty K (2008) The interaction of human neuroglobin with hydrogen sulphide. IUBMB Life. 60 $135-138$

52. Watanabe K, Suzuki T, Kitagishi H, Kano K (2015) Reaction between a haemoglobin model compound and hydrosulphide in aqueous solution. Chem Commun 51:4059-4061

53. Nicoletti FP, Comandini A, Bonamore A, Boechi L, Boubeta FM, Feis A, Smulevich G, Boffi A (2010) Sulfide binding properties of truncated hemoglobins. Biochemistry. 49:2269-2278

54. Tiranti V, D'Adamo P, Briem E, Ferrari G, Mineri R, Lamantea E, Mandel H, Balestri P, Garcia-Silva M-T, Vollmer B, Rinaldo P, Hahn SH, Leonard J, Rahman S, Dionisi-Vici C, Garavaglia B, Gasparini P, Zeviani M (2004) Ethylmalonic encephalopathy is caused by mutations in ETHE1, a gene encoding a mitochondrial matrix protein. Am J Hum Genet. 74:239-252

55. Tiranti V, Briem E, Lamantea E, Mineri R, Papaleo E, De Gioia L, Forlani F, Rinaldo P, Dickson P, Abu-Libdeh B, CindroHeberle L, Owaidha M, Jack RM, Christensen E, Burlina A, Zeviani M (2006) ETHE1 mutations are specific to ethylmalonic encephalopathy. J Med Genet. 43:340-346

56. Mineri R, Rimoldi M, Burlina AB, Koskull S, Perletti C, Heese B, von Döbeln U, Mereghetti P, Di Meo I, Invernizzi F, Zeviani M, Uziel G, Tiranti V (2008) Identification of new mutations in the ETHE1 gene in a cohort of 14 patients presenting with ethylmalonic encephalopathy. J Med Genet. 45:473 
57. Morton NM, Beltram J, Carter RN, Michailidou Z, Gorjanc G, Mc Fadden C, Barrios-Llerena ME, Rodriguez-Cuenca S, MTG G, Aird RE, Moreno-Navarrete JM, Munger SC, Svenson KL, Gastaldello A, Ramage L, Naredo G, Zeyda M, Wang ZV, Howie AF, Saari A, Sipilä P, Stulnig TM, Gudnason V, Kenyon CJ, Seckl JR, Walker BR, Webster SP, Dunbar DR, Churchill GA, Vidal-Puig A, Fernandez-Real JM, Emilsson V, Horvat S (2016) Genetic identification of thiosulfate sulfurtransferase as an adipocyte-expressed antidiabetic target in mice selected for leanness. Nat Med 22:771-779

58. Elrod JW, Calvert JW, Morrison J, Doeller JE, Kraus DW, Tao L, Jiao X, Scalia R, Kiss L, Szabo C, Kimura H, Chow C-W, Lefer DJ (2007) Hydrogen sulfide attenuates myocardial ischemia-reperfusion injury by preservation of mitochondrial function. Proc Natl Acad Sci U S A 104:15560-15565

59. Minamishima S, Bougaki M, Sips PY, De Yu J, Minamishima YA, Elrod JW, Lefer DJ, Bloch KD, Ichinose F (2009) Hydrogen sulfide improves survival after cardiac arrest and cardiopulmonary resuscitation via a nitric oxide synthase 3-dependent mechanism in mice. Circulation. 120:888-896

60. Marutani E, Kosugi S, Tokuda K, Khatri A, Nguyen R, Atochin DN, Kida K, Van Leyen K, Arai K, Ichinose F (2012) A novel hydrogen sulfide-releasing $\mathrm{N}$-methyl-D-aspartate receptor antagonist prevents ischemic neuronal death. J Biol Chem 287:32124-32135

61. Shen X, Pattillo CB, Pardue S, Bir SC, Wang R, Kevil CG (2011) Measurement of plasma hydrogen sulfide in vivo and in vitro. Free Radic Biol Med 50:1021-1031

62. Powell CR, Dillon KM, Matson JB (2018) A review of hydrogen sulfide $\left(\mathrm{H}_{2} \mathrm{~S}\right)$ donors: chemistry and potential therapeutic applications. Biochem Pharmacol 149:110-123

63. Rose P, Dymock BW, Moore PK (2015) Chapter nine - GYY4137, a novel water-soluble, $\mathrm{H}_{2}$ S-releasing molecule. In: Cadenas E, Packer L (eds) Methods in enzymology. Academic Press, pp 143-167

64. Chen MJ, Peng ZF, Manikandan J, Melendez AJ, Tan GS, Chung CM, Li Q-T, Tan TM, Deng LW, Whiteman M, Beart PM, Moore PK, Cheung NS (2011) Gene profiling reveals hydrogen sulphide recruits death signaling via the N-methyl-Daspartate receptor identifying commonalities with excitotoxicity. J Cell Physiol 226:1308-1322

65. Qu K, Chen CPLH, Halliwell B, Moore PK, Wong PT-H (2006) Hydrogen sulfide is a mediator of cerebral ischemic damage. Stroke. 37:889-893

66. Cheung NS, Peng ZF, Chen MJ, Moore PK, Whiteman M (2007) Hydrogen sulfide induced neuronal death occurs via glutamate receptor and is associated with calpain activation and lysosomal rupture in mouse primary cortical neurons. Neuropharmacology. 53:505-514

67. Wallace JL, Nagy P, Feener TD, Allain T, Ditrói T, Vaughan DJ, Muscara MN, de Nucci G, Buret AG A proof-of-concept, phase 2 clinical trial of the gastrointestinal safety of a hydrogen sulfide-releasing anti-inflammatory drug. Br J Pharmacol

68. Polhemus DJ, Li Z, Pattillo CB, Gojon G Sr, Gojon G Jr, Giordano T, Krum H (2015) A novel hydrogen sulfide prodrug, SG1002, promotes hydrogen sulfide and nitric oxide bioavailability in heart failure patients. Cardiovasc Ther. 33:216-226

69. Wen Y-D, Wang H, Zhu Y-Z (2018) The drug developments of hydrogen sulfide on cardiovascular disease. Oxid Med Cell Longev 2018:21

70. Tokuda K, Kida K, Marutani E, Crimi E, Bougaki M, Khatri A, Kimura H, Ichinose F (2012) Inhaled hydrogen sulfide prevents endotoxin-induced systemic inflammation and improves survival by altering sulfide metabolism in mice. Antioxid Redox Signal 17:11-21

71. King AL, Polhemus DJ, Bhushan S, Otsuka H, Kondo K, Nicholson CK, Bradley JM, Islam KN, Calvert JW, Tao Y-X, Dugas TR, Kelley EE, Elrod JW, Huang PL, Wang R, Lefer DJ (2014) Hydrogen sulfide cytoprotective signaling is endothelial nitric oxide synthase-nitric oxide dependent. Proc Natl Acad Sci 111:3182-3187

72. Salloum FN, Chau VQ, Hoke NN, Abbate A, Varma A, Ockaili RA, Toldo S, Kukreja RC (2009) Phosphodiesterase-5 inhibitor, tadalafil, protects against myocardial ischemia/reperfusion through protein-kinase G-dependent generation of hydrogen sulfide. Circulation. 120:S31-S36

73. George TJ, Arnaoutakis GJ, Beaty CA, Jandu SK, Santhanam L, Berkowitz DE, Shah AS Inhaled hydrogen sulfide improves graft function in an experimental model of lung transplantation. J Surg Res 178:593-600

74. Nigwekar SU, Thadhani R, Brandenburg VM (2018) Calciphylaxis. N Engl J Med 378:1704-1714

75. Libiad M, Motl N, Akey DL, Sakamoto N, Fearon ER, Smith JL, Banerjee R (2018) Thiosulfate sulfurtransferase-like domaincontaining 1 protein interacts with thioredoxin. J Biol Chem 293:2675-2686

76. Sakaguchi M, Marutani E, Shin H-S, Chen W, Hanaoka K, Xian M, Ichinose F (2014) Sodium thiosulfate attenuates acute lung injury in mice. Anesthesiology 121:1248-1257. https://doi.org/10.1097/ALN.0000000000000456

77. Vitvitsky V, Yadav PK, An S, Seravalli J, Cho U-S, Banerjee R (2017) Structural and mechanistic insights into hemoglobincatalyzed hydrogen sulfide oxidation and the fate of polysulfide products. J Biol Chem 292:5584-5592

78. Hessel PA, Herbert FA, Melenka LS, Yoshida K, Nakaza M (1997) Lung health in relation to hydrogen sulfide exposure in oil and gas workers in Alberta, Canada. Am J Ind Med 31:554-557

79. Maebashi K, Iwadate K, Sakai K, Takatsu A, Fukui K, Aoyagi M, Ochiai E, Nagai T (2011) Toxicological analysis of 17 autopsy cases of hydrogen sulfide poisoning resulting from the inhalation of intentionally generated hydrogen sulfide gas. Forensic Sci Int 207:91-95

80. Reedy SJD, Schwartz MD, Morgan BW (2011) Suicide fads: frequency and characteristics of hydrogen sulfide suicides in the United States. West J Emerg Med. 12:300-304

81. Guidotti TL (2015) Hydrogen sulfide intoxication. Handb Clin Neurol 131:111-133

82. Kilburn KH, Thrasher JD, Gray MR (2010) Low-level hydrogen sulfide and central nervous system dysfunction. Toxicol Ind Health 26:387-405

83. Luther GW 3rd, Findlay AJ, Macdonald DJ, Owings SM, Hanson TE, Beinart RA, Girguis PR (2011) Thermodynamics and kinetics of sulfide oxidation by oxygen: a look at inorganically controlled reactions and biologically mediated processes in the environment. Front Microbiol. 2:62-62

84. Malagrinò F, Zuhra K, Mascolo L, Mastronicola D, Vicente JB, Forte E, Giuffrè A (2019) Hydrogen sulfide oxidation: adaptive changes in mitochondria of SW480 colorectal cancer cells upon exposure to hypoxia. Oxid Med Cell Longev 2019:8102936-8102936

85. Ikeda K, Marutani E, Hirai S, Wood ME, Whiteman M, Ichinose F (2015) Mitochondria-targeted hydrogen sulfide donor AP39 improves neurological outcomes after cardiac arrest in mice. Nitric Oxide. 49:90-96 
86. Knapp J, Heinzmann A, Schneider A, Padosch SA, Böttiger BW, Teschendorf P, Popp E (2011) Hypothermia and neuroprotection by sulfide after cardiac arrest and cardiopulmonary resuscitation. Resuscitation. 82:1076-1080

87. Arndt S, Baeza-Garza CD, Logan A, Rosa T, Wedmann R, Prime TA, Martin JL, Saeb-Parsy K, Krieg T, Filipovic MR, Hartley RC, Murphy MP (2017) Assessment of $\mathrm{H}_{2} \mathrm{~S}$ in vivo using the newly developed mitochondria-targeted mass spectrometry probe Mitoa. J Biol Chem.

88. Szabo G, Veres G, Radovits T, Gero D, Modis K, Miesel-Groschel C, Horkay F, Karck M, Szabo C (2011) Cardioprotective effects of hydrogen sulfide. Nitric Oxide. 25:201-210

89. Derwall M, Westerkamp M, Lower C, Deike-Glindemann J, Schnorrenberger NK, Coburn M, Nolte KW, Gaisa N, Weis J, Siepmann K, Hausler M, Rossaint R, Fries M (2010) Hydrogen sulfide does not increase resuscitability in a porcine model of prolonged cardiac arrest. Shock. 34:190-195

90. Yang C-T, Wang Y, Marutani E, Ida T, Ni X, Xu S, Chen W, Zhang H, Akaike T, Ichinose F, Xian M (2019) Data-driven identification of hydrogen sulfide scavengers. Angew Chem Int Ed Engl 58:10898-10902

91. Agbroko OW, Piler K, Benson TJ (2017) A comprehensive review of $\mathrm{H}_{2} \mathrm{~S}$ scavenger technologies from oil and gas streams. Chem Bio Eng Rev 4:339-359

92. Brenner M, Benavides S, Mahon SB, Lee J, Yoon D, Mukai D, Viseroi M, Chan A, Jiang J, Narula N, Azer SM, Alexander C, Boss GR (2014) The vitamin B12 analog cobinamide is an effective hydrogen sulfide antidote in a lethal rabbit model. Clin Toxicol (Phila) 52:490-497

93. Jiang J, Chan A, Ali S, Saha A, Haushalter KJ, Lam WL, Glasheen M, Parker J, Brenner M, Mahon SB, Patel HH, Ambasudhan R, Lipton SA, Pilz RB, Boss GR (2016) Hydrogen sulfide--mechanisms of toxicity and development of an antidote. Sci Rep 6:20831

94. Truong DH, Mihajlovic A, Gunness P, Hindmarsh W, O'Brien PJ (2007) Prevention of hydrogen sulfide $\left(\mathrm{H}_{2} \mathrm{~S}\right)$-induced mouse lethality and cytotoxicity by hydroxocobalamin (vitamin B(12a)). Toxicology. 242:16-22

95. Bos EM, van Goor H, Joles JA, Whiteman M, Leuvenink HG (2015) Hydrogen sulfide: physiological properties and therapeutic potential in ischaemia. Br J Pharmacol. 172:1479-1493

96. Papapetropoulos A, Whiteman M, Cirino G (2015) Pharmacological tools for hydrogen sulphide research: a brief, introductory guide for beginners. Br J Pharmacol 172:1633-1637

97. Wallace JL, Blackler RW, Chan MV, Da Silva GJ, Elsheikh W, Flannigan KL, Gamaniek I, Manko A, Wang L, Motta JP, Buret AG (2015) Anti-inflammatory and cytoprotective actions of hydrogen sulfide: translation to therapeutics. Antioxid Redox Signal 22:398-410

98. Predmore BL, Lefer DJ, Gojon G (2012) Hydrogen sulfide in biochemistry and medicine. Antioxid Redox Signal. 17:119140

99. Panagaki T, Randi EB, Augsburger F, Szabo C (2019) Overproduction of $\mathrm{H}_{2} \mathrm{~S}$, generated by CBS, inhibits mitochondrial complex IV and suppresses oxidative phosphorylation in Down syndrome. Proc Natl Acad Sci 116:18769-18771

\section{Publisher's Note}

Springer Nature remains neutral with regard to jurisdictional claims in published maps and institutional affiliations.

\section{Submit your manuscript to a SpringerOpen ${ }^{\circ}$ journal and benefit from:}

- Convenient online submission

- Rigorous peer review

- Open access: articles freely available online

- High visibility within the field

- Retaining the copyright to your article

Submit your next manuscript at $>$ springeropen.com 